\title{
DECENTRALIZED TAXATION AND THE SIZE OF GOVERNMENT: EVIDENCE FROM SWISS STATE AND LOCAL GOVERNMENTS
}

\author{
LARS P. FELD \\ GEBHARD KIRCHGÄSSNER \\ CHRISTOPH A. SCHALTEGGER
}

CESIFO WORKING PAPER NO. 1087

CATEGORY 1: Public FinANCE

NOVEMBER 2003

Presented at $3^{\text {RD }}$ Norwegian-German Seminar on Public Economics, June 2003

An electronic version of the paper may be downloaded

- from the SSRN website:

www.SSRN.com

- from the CESifo website: www.CESifo.de 


\title{
DECENTRALIZED TAXATION AND THE SIZE OF GOVERNMENT: EVIDENCE FROM SWISS STATE AND LOCAL GOVERNMENTS
}

\begin{abstract}
According to the Leviathan-Model, fiscal federalism is seen as a binding constraint on a revenue-maximizing government. The competitive pressure of fiscal federalism is supposed to reduce public sector size as compared to unitary states. However, empirical results concerning the Leviathan hypothesis are mixed. This study uses a state and local-level panel data set of Swiss cantons from 1980 to 1998 to empirically analyze the effect of different federalist institutions on the size and structure of government revenue. Because of the considerable tax autonomy of sub-national Swiss governments, it is possible to investigate different mechanisms by which fiscal federalism may influence government size. The results indicate that tax exporting has a revenue expanding effect whereas tax competition favors a smaller size of government. Fragmentation has essentially no effect on the size of government revenue for Swiss cantons. The overall effect of revenue decentralization leads to fewer tax revenue but higher user charges. Thus, revenue decentralization favors a smaller size of government revenue and shifts government revenue from taxes to user charges.
\end{abstract}

JEL Classification: D7, D72, H71.

Keywords: federalism, government revenue, tax competition, tax exporting.

Lars P. Feld
Philipps-University Marburg
Public Finance Group
Am Plan 2
35037 Marburg (Lahn)
Germany
feld@wiwi.uni-marburg.de

Gebhard Kirchgässner

University of St. Gallen

SIAW, Institutsgebäude

Dufourstr. 48

CH-9000 St. Gallen

Switzerland

Gebhard.Kirchgaessner@unisg.ch

\author{
Christoph A. Schaltegger \\ University of St. Gallen \\ SIAW, Institutsgebäude \\ Dufourstr. 48 \\ CH-9000 St. Gallen \\ Switzerland
}

Previous versions of this paper have been presented at the Economics Seminar, University of Rennes, 2003, the Annual Meeting of the Public Choice Society, Aarhus, 2003, the Annual Meeting of the Canadian Public Economics Study Group, Ottawa, 2003, the Economics Seminar, Carleton University, Ottawa, 2003, the Third Norwegian-German Seminar on Public Economics at CESifo, Munich, 2003 and the Annual Meeting of the International Institute of Public Finance, Prague, 2003. We thank the participants of these discussions for helpful comments and suggestions. We would also like to acknowledge a grant from the Swiss National Science Foundation (Grant-No. 5004-58524). 
It is better to keep the wolf out of the fold, than to trust to drawing his teeth and claws after he shall have entered.

Thomas Jefferson ${ }^{l}$

\section{Introduction}

Taxation enables governments to gain effective political power. Understanding political decisions in the public sector thus requires knowledge about the power to tax of different government tiers and the impact of the allocation of taxing powers on government finances. Following Hettich and Winer $(1988,1997)$, tax systems are the outcome of an interaction between rational (private and public) agents who maximize their utility in a framework of collective decision making. In this framework, the fiscal behavior of a government is basically constraint by exit and voice (Hirschman 1970). Voice in the public sector can be exerted by democratic decision-making procedures, like competitive elections, popular referendums or voter initiatives, while exit requires the possibility of citizens migrate and hence vote by feet.

The literature on the impact of electoral competition as an investigation of the voice mechanism starts with the median voter model explaining the observable tax system under majority rule (Romer 1975, Roberts 1977, Meltzer and Richard 1981, 1983). An extension to this literature is discussed by Matsusaka (1995) and Feld and Matsusaka (2002). They distinguish between revenue systems in direct vs. representative democratic systems and provide empirical evidence that in jurisdictions with fiscal referendums government finances rely more on user charges than on tax revenues and that tax revenues are lower in a direct democracy compared to a representative democratic system. A related approach focuses on the impact of federalism on government behavior as an investigation of the exit mechanism (Oates 1972, 1985, 1999, Brennan and Buchanan 1977, 1978, 1980). As argued by Brennan and Buchanan, the government is able to behave like a revenue maximizing monopoly called a Leviathan. In a centralized system where only the federal level possesses taxing powers, it is more difficult to restrict such Leviathan behavior than in a strongly decentralized system with considerable powers of state and local governments. If different units of government have to share their tax base, the threat of migration imposes a serious restriction on government behavior. ${ }^{2}$

1. Quoted according to Brennan and Buchanan (1980, p. 168)

2. The problem of vertical fiscal externalities that might occur in a multi-level federalism is not discussed by Brennan and Buchanan (1980) or Oates (1972). A theoretical analysis of vertical fiscal externalities can be found in Wrede (1996) or Keen and Kotsogiannis (2002). 
In the empirical literature on the relationship between government decentralization and go vernment size, whether and how fiscal decentralization affects government size is still not clarified. In particular the potential transmission channels through which decentralization reduces public sector size are not investigated explicitly. The purpose of this paper is to analyze empirically whether a decentralization of the power to tax to sub-federal jurisdictions has an impact on the size and structure of government revenue of Swiss cantons from 1980 to 1998. The main emphasis is on the different mechanisms by which revenue decentralization might influence the size of the public sector. We distinguish tax competition, tax exporting and fragmentation as three potential transmission mechanisms that affect government size. The residual impact of decentralization is interpreted as evidence for laboratory federalism (Oates 1999). Switzerland is particularly suited for such a test because it provides unique data of subfederal governments that have extensive autonomy in choosing tax instruments including also quantitatively important and progressive taxes on income and property.

The remainder of the paper is organized as follows: The different transmission channels by which fiscal federalism affects government size are discussed in Section 2. Section 3 surveys the empirical literature on the impact of fiscal federalism on the size and scope of government revenue. In Section 4, the Swiss tax system is explained in order to demonstrate the importance of sub-federal Swiss taxing powers. Data and the specification of our empirical model appear in Section 5 while Section 6 discusses the obtained results. Finally, Section 7 provides some concluding remarks.

\section{Transmission Channels of Fiscal Federalism on the Size of Government}

According to Brennan and Buchanan, emigration imposes a serious restriction on the ability of governments to exploit tax bases. If emigration is possible at low cost, tax bases can avoid excessive taxation by leaving the jurisdiction that levies taxes. In their decentralization hypothesis Brennan and Buchanan (1980, p. 185) conclude: "total government intrusion into the economy should be smaller, ceteris paribus, the greater the extent to which taxes and expenditures are decentralized". A similar interpretation of fiscal federalism is provided by Oates (1972). He argues that political agents have a better knowledge of the preferences of their constituency if the fiscal power is decentralized, such that the provision of public goods can be tailored more efficiently to their needs. The Wicksellian (1896) connection of spending and taxing decisions is much tighter on the local than on the federal level. ${ }^{3}$ According to

3. Winer (1983) provides empirical evidence that the separation of spending and taxing decisions in Canadian provinces through the introduction of federal grants caused higher provincial expenditures. 
Oates (1972) the Wicksellian connection favors a smaller size of government. On the other hand, as Oates (1985) mentions, if local governments have more information about the preferences of citizens than central governments and, therefore, public services can be better tailored to the needs of voters, this might increase their demand for public spending leading to a larger share of government. ${ }^{4}$ In a somewhat different analysis, Persson and Tabellini (1994, 2000) theoretically show the importance of decentralization in restricting government discretion to exploit the fiscal commons. Wildasin (1997) follows a similar line of thought by concluding that fiscal indiscipline of sub-federal governments as a result of bail-outs by the central government is of minor relevance in a fragmented federalism where sub-federal units are not considered as being too big to fail. ${ }^{5}$

Despite the emphasis on exit as a disciplinary device, it is not clear which mechanism is supposed to lead to a smaller government sector in the first place. Additionally to the decentralization hypothesis, Brennan and Buchanan $(1977,1978,1980)$ hence develop a fragmentation hypothesis: The competitive impact of fiscal federalism depends on the number of possible alternative jurisdictions that are available for voters and firms and the transaction costs that migrations induce. They argue: "the potential for fiscal exploitation varies inversely with the number of competing governmental units in the inclusive territory" (Brennan and Buchanan, 1980, p. 185). In a theoretical analysis, Epple and Zelenitz (1981) show, that with increasing numbers of jurisdictional units, the scope for taxation diminishes although it does not disappear entirely. Of course, decentralization and fragmentation could also lead to inefficiencies since increasing returns to scale in the consumption of public goods can be exploited to a lesser extent (Sinn 1997, 2003). The result might be a larger public sector because economies of scale are not exploited and the provision of public services becomes more inefficient.

A second argument for the dampening impact of decentralization on government size stems from the tax competition literature, and could be called the tax competition hypothesis (see Wilson 1999 for a survey). In particular with respect to public revenue, a more intense tax competition will lead to lower tax rates of the mobile higher income recipients and thus to lower tax revenue. Mobile taxpayers move to jurisdictions with - ceteris paribus - lower tax rates. The lower the mobility costs the higher the pressure for a jurisdiction will be to compete

4. Oates (1985, p. 749) refers to the American economic historian Wallis claiming that this hypothesis is based on observations from American history.

5. Qian and Roland (1998) study two effects of federalism: First, a 'competition effect' which increases the opportunity costs of bail-outs and serves as a commitment device for the government under factor mobility; second, a 'checks and balance effect' which serves as a hard budget constraint. Rodden (2002) shows that intergovernmental grants induce fiscal indiscipline of sub-federal governments through bail-out. 
with other jurisdictions by lowering tax rates as well. The result is a smaller government sector. In contrast to the Leviathan model which has revenue maximizing governments by assumption, the tax competition literature evaluates such a government as inefficiently small however, because the go vernment is supposed to do 'what it ought to' (Sinn 1997).

The pressure to reduce the size and scope of the public sector by a decentralization of government is reduced by the possibility of tax exporting (tax exporting hypothesis). Taxes are exported to nonresidents if they pay some of the taxes of sub-federal jurisdictions. State and local governments thus have an incentive to provide public services at a higher level than their residents prefer. An example of tax exporting can be found in the taxation of tourist trade or of natural resources in some U.S. states. Already for the year 1962, McLure (1967) estimated for the U.S. states that overall tax export rates were between 19 and 28 percent in the short run. Tax exporting need not be restricted to natural resource taxes. It is also possible in the case of corporate income taxes on foreign owned firms (Sørensen 2002).

While Oates (1972) emphasizes the advantage of a decentralized government with respect to preference costs of centralized provision of public services, Oates (1999) more strongly underlines the role of laboratory federalism. A decentralized competitive government structure allows for an experimentation of new public policies without doing too much harm if they fail. Successful government policies in one jurisdiction are imitated and adapted by other jurisdictions at the same, lower or higher government level. Federalism then becomes a discovery procedure for new public solutions (Schnellenbach 2003). Weingast (1995) argues that the discovery mechanism of government decentralization tends to promote policies that are closer to market solutions. The author therefore speaks of market-preserving federalism and hypothesizes a smaller government sector. The market-preserving role of fiscal federalism as a means to reduce the public sector could thus be called the discovery hypothesis.

\section{Review on the Empirical Literature}

Numerous researchers have been concerned with the impact of fiscal federalism on the size of government. The results are however inconclusive and, moreover, the different transmission channels are not empirically distinguished yet. Oates (1972, p. 209-213) uses a cross-section of 57 countries to evaluate the empirical relevance of the decentralization hypothesis. As a proxy for the size of government he uses tax revenues as a share of national income while the fiscal centralization variable is constructed by the ratio of central-government tax revenues on total tax revenues. In a bivariate regression, Oates (1972) finds a significant negative relationship between the centralization ratio and the size of government. However, when additionally 
controlling for income, the impact of centralization on the size of government becomes insignificant. In a subsequent analysis, Oates (1985) uses two different data sets. The first consists of the 48 contiguous states in the United States, the second of 43 countries in 1982. In a multiple regression analysis he does again not find a statistically significant impact of fiscal decentralization on the size of government. Similar results are obtained when he uses the number of local governments, of local governments per geographic area or of local governments per population size as proxies for fiscal federalism (fragmentation hypothesis).

In addition, Forbes and Zampelli (1989) find a statistically significant positive impact of decentralization on the size of government for a sample of 345 counties at the standard metropolitan statistical area (SMSA) level suggesting the opposite of the Leviathan hypothesis. Similarly, Wallis and Oates (1988a) provide empirical evidence in a large historical panel data set from the beginning of the century until the $1980^{\text {ies }}$ that more fiscally decentralized states favor higher public spending. Stein (1999) provides empirical evidence supporting these results with an expanding effect of decentralization on the size of government in a crosssection analysis for 19 Latin American countries for an average between 1990 and 1995.

Nelson (1987) criticizes the proxy for decentralization used by Oates (1985). He argues that in Oates' data set nearly one third of all governments are special districts. Most of them only provide one single public service like for example cemetery services and one-third of them have no taxing powers (Nelson, 1987, p. 199). Jurisdictions with limited governmental functions and taxing powers are not directly comparable with general-purpose governments. Therefore, Nelson (1987) distinguishes between data drawn from general-purpose and singlepurpose jurisdictions of 48 US states for the fiscal year 1977. His results indicate a fairly robust support for the fragmentation hypothesis for general-purpose jurisdictions but not for single-purpose jurisdictions. Much the same can be concluded from the study by Eberts and Gronberg (1988) who use data from the standard metropolitan statistical area (SMSA) level. In an empirical investigation of the Olson (1982) hypothesis of economic sclerosis as a result of the time length of a politically stable environment, Wallis and Oates (1988b) provide evidence in a panel analysis from selected years between 1902 to 1982 (432 observations) that fiscal concentration is positively related to the size of state and local governments. In a crosssection regression among 3022 counties, Zax (1989) provides evidence in favor of both the fragmentation and decentralization hypotheses using data from 1982. In addition, Raimondo (1989) investigates the effect of federalism on specific spending categories, suggesting that the decentralization hypothesis may hold for some public services but not for others. 
Table 1: Empirical results on the impact of federalism on the size of government

\begin{tabular}{|c|c|c|c|c|c|}
\hline Authors & Size of government & Federalism & Sample & Time & Result \\
\hline Oates (1972) & Total government revenue / national income & Central government revenue / total government revenue & 57 countries & 1972 & No support \\
\hline DiLorenzo (1983) & $\begin{array}{l}\text { Local government spending per capita (general } \\
\text { expenditure, police, fire protection, highway, } \\
\text { sanit ation and welfare) }\end{array}$ & $\begin{array}{l}\text { Total county government expenditure (tax revenue) / government } \\
\text { expenditure (tax revenue) in the four largest jurisdictions }\end{array}$ & 65 large SMSA & 1975 & $\begin{array}{l}\text { Support for expenditure } \\
\text { No support for tax } \\
\text { revenue }\end{array}$ \\
\hline Solano (1983) & 22 government expenditure measures & $\begin{array}{l}\text { Dummy variable for federalist countries (Australia, Canada, } \\
\text { Switzerland, United States and Germany) and central government } \\
\text { tax revenue / total government tax revenue }\end{array}$ & 18 countries & 1968 & Support \\
\hline \multirow[t]{2}{*}{ Oates (1985) } & Total government revenue / GDP & $\begin{array}{l}\text { Central government revenue (expenditure) / total government } \\
\text { revenue (expenditure) }\end{array}$ & 43 IMF countries & 1982 & No support \\
\hline & State government revenue / personal income & $\begin{array}{l}\text { State government revenue (expenditure) / State and local govem- } \\
\text { ment revenue (expenditure) and total number of governmental } \\
\text { units in a state }\end{array}$ & $\begin{array}{l}48 \text { contiguous US } \\
\text { states }\end{array}$ & 1977 & No support \\
\hline \multirow[t]{2}{*}{ Nelson (1986) } & $\begin{array}{l}\text { State and local taxes per capita (per personal } \\
\text { income) }\end{array}$ & State share of total state and local taxes and & 49 US states & 1976 & No support \\
\hline & $\begin{array}{l}\begin{array}{l}\text { State and local taxes per capita (per personal } \\
\text { income) }\end{array}\end{array}$ & Population of a state divided by the total number of counties & 49 US states & 1976 & Support \\
\hline Schneider (1986) & Growth of local govemments & Total number of suburban municipal governments & 46 large SMSA & $1972-1977$ & No support \\
\hline Nelson (1987) & $\begin{array}{l}\text { State and local government revenue (expendi- } \\
\text { ture) / personal income }\end{array}$ & $\begin{array}{l}\text { Total number of general purpose governments and total number } \\
\text { of special purpose govemments }\end{array}$ & 50 US states & 1977 & Support \\
\hline Marlow (1988) & Total government expenditure / GNP & State and local expenditure / Total government expenditure & United States & $1946-1985$ & Support \\
\hline $\begin{array}{l}\text { Eberts and Gronberg } \\
\text { (1988) }\end{array}$ & State and local expenditure / personal income & $\begin{array}{l}\text { Total number of general purpose governments and total number } \\
\text { of special purpose govemments }\end{array}$ & 280 SMSA & 1977 & Support \\
\hline Wallis and Oates (1988a) & State revenue (expenditure) / personal income & $\begin{array}{l}\text { State revenue (expenditure) / state and local revenue (expendi- } \\
\text { ture) }\end{array}$ & $\begin{array}{l}48 \text { contiguous US } \\
\text { states }\end{array}$ & $1902-1982$ & Support \\
\hline $\begin{array}{l}\text { Wallis and Oates } \\
\text { (1988b) }\end{array}$ & $\begin{array}{l}\text { State and local revenue (expenditure) / per } \\
\text { capita income }\end{array}$ & $\begin{array}{l}\text { State revenue (expenditure) / state and local revenue (expendi- } \\
\text { ture) }\end{array}$ & $\begin{array}{l}48 \text { contiguous US } \\
\text { states }\end{array}$ & $1902-1982$ & Support \\
\hline Saunders (1988) & Total government expenditure / GDP & Dummy variable for federalist countries & 22 OECD countries & $\begin{array}{l}\text { Average 1960- } \\
1962 \text { and } 1978- \\
1980\end{array}$ & Support \\
\hline Grossman (1989) & Total government expenditure / GNP & State and local expenditure / Total government expenditure & United States & $1946-1986$ & Support \\
\hline $\begin{array}{l}\text { Forbes and Zampelli } \\
\text { (1989) }\end{array}$ & $\begin{array}{l}\text { County government revenue per capita, county } \\
\text { government revenue / personal income, county } \\
\text { government own revenue / personal income }\end{array}$ & Total number of county go vernment in SMSA & 157 SMSA & 1977 & No support \\
\hline
\end{tabular}


Table 1 (continued): Empirical results on the impact of federalism on the size of government

\begin{tabular}{|c|c|c|c|c|c|}
\hline Authors & Size of government & Federalism & Sample & Time & Result \\
\hline Zax (1989) & $\begin{array}{l}\text { County government share of local total revenue/ } \\
\text { personal income }\end{array}$ & $\begin{array}{l}\text { Total number of general purpose governments per square mile } \\
\text { and total number of special purpose governments per square mile } \\
\text { and County government share of local total revenue / total gov- } \\
\text { ernment revenue }\end{array}$ & 3022 counties & 1982 & Support \\
\hline Raimondo (1989) & $\begin{array}{l}\text { State and local government expenditure / per- } \\
\text { sonal income for six expenditure categories } \\
\text { (total, education, welfare, hospital, highways, all } \\
\text { other) }\end{array}$ & $\begin{array}{l}\text { Central government expenditure / state and local expenditure and } \\
\text { local government expenditure / state and local expenditure }\end{array}$ & 50 US states & $1960,1970,1980$ & Support \\
\hline $\begin{array}{l}\text { Joulfaian and Marlow } \\
\text { (1990) }\end{array}$ & $\begin{array}{l}\text { Total government expenditure / gross state } \\
\text { product }\end{array}$ & $\begin{array}{l}\text { State and local expenditure / total government expenditure and } \\
\text { total governmental units in a state }\end{array}$ & 48 US states & 1981,1984 & Support \\
\hline $\begin{array}{l}\text { Joulfaian and Marlow } \\
\text { (1991) }\end{array}$ & $\begin{array}{l}\text { Total government expenditure / gross state } \\
\text { product and total government expenditure per } \\
\text { capita }\end{array}$ & $\begin{array}{l}\text { Local government expenditure / state and local government } \\
\text { expenditure and state and local government expenditure / Total } \\
\text { government expenditure and total number of local governments in } \\
\text { SMSA }\end{array}$ & 48 US states & $1983-1985$ & Support \\
\hline Heil (1991) & Total government revenue (expenditure) / GDP & Dummy variable for federalist countries & $\begin{array}{l}22 \text { OECD countries } \\
\text { and } 39 \text { IMF countries }\end{array}$ & 1985 & No support \\
\hline $\begin{array}{l}\text { Grossman and West } \\
\text { (1994) }\end{array}$ & Total government expenditure / GNP & $\begin{array}{l}\text { State and local government expenditure / total government ex- } \\
\text { penditure }\end{array}$ & Canada & 1958-1987 & Support \\
\hline Shadbegian (1999) & $\begin{array}{l}\text { Total government expenditure / gross state } \\
\text { product }\end{array}$ & $\begin{array}{l}\text { State and local government expenditure / total government ex- } \\
\text { penditure }\end{array}$ & 48 US states & 1979-1992 & Support \\
\hline $\begin{array}{l}\text { Moesen and van } \\
\text { Cauwenberge (2000) }\end{array}$ & Total government expenditure / GDP & $\begin{array}{l}\text { Local government expenditure minus transfers received / total } \\
\text { government expenditure }\end{array}$ & 19 OECD countries & $1990-1992$ & Support \\
\hline Schaltegger (2001) & $\begin{array}{l}\text { State and local government expenditure per } \\
\text { capita (all expenditure categories) }\end{array}$ & $\begin{array}{l}\text { Local government expenditure / State and local government } \\
\text { expenditure (all expenditure categories) and total number of local } \\
\text { governments }\end{array}$ & 26 Swiss cantons & $1980-1998$ & Support \\
\hline Kirchgässner (2002a) & $\begin{array}{l}\text { State and local government expenditure per } \\
\text { capita (total expenditure and total revenue) }\end{array}$ & $\begin{array}{l}\text { Local government expenditure (revenue) / State and local gov- } \\
\text { ernment expenditure (revenue) and number of local governments } \\
\text { divided by the cantonal population }\end{array}$ & 26 Swiss cantons & $1980-1998$ & Support \\
\hline Jin and Zou (2002) & $\begin{array}{l}\text { National, subnational or aggregate expenditure } \\
\text { in percent of GDP }\end{array}$ & $\begin{array}{l}\text { Ratio of subnational to total government expenditure, ratio of } \\
\text { subnational to total government revenue, percentage of subna- } \\
\text { tional expenditure financed by central transfers }\end{array}$ & $\begin{array}{l}17 \text { industrial and } 15 \\
\text { developing countries }\end{array}$ & 1980-1994 & $\begin{array}{l}\text { No support for spending } \\
\text { Support for revenue } \\
\text { measure }\end{array}$ \\
\hline Rodden (2003) & $\begin{array}{l}\text { Total government expenditure in percent of } \\
\text { GDP }\end{array}$ & Own source subnational revenue in percent of total revenue & 59 countries & 1978-1997 & Support \\
\hline
\end{tabular}


One objection against the empirical results focuses on the impact of federal grants to the states. Following the theoretical model by Weingast, Shepsle and Johnson (1981), grants from the central level that are financed nationwide cause serious externalities as long as these grants can be used for geographically targeted public services. According to the Leviathan model by Brennan and Buchanan, systems of intergovernmental grants can be seen as a form of collusive agreements by the sub-federal governments to circumvent the competitive power of fiscal federalism. In a time series analysis of US states Grossman (1989) and of Canadian provinces Grossman and West (1994) additionally control for grants and find support for the collusion hypothesis. The same holds for the studies by Wyckoff (1991), Hines and Thaler (1995) and Jones, Sanguinetti and Tommasi (1999). Including federal transfer payments to the US states, Shadbegian (1999) also confirms the decentralization hypothesis in a panel analysis from 1979 to 1992 for the US states. Schaltegger (2001) gets similar results for public spending and Kirchgässner (2002a) for public spending as well as revenue each in a panel of 26 Swiss cantons from 1980 to 1998. In a cross-country study for 32 states between 1980 and 1994, Jin and Zou (2002) present evidence that vertical fiscal imbalance measured as the percentage of subnational expenditure financed by grants from the central government increases expenditure. In addition, their results show that expenditure decentralization does not, while revenue decentralization does effectively restrict the size of government. Rodden (2003) also employs an (unbalanced) panel data set of up to 59 countries between 1978 and 1997. According to his results, decentralization measured by own source subnational revenue in percent of total revenue decreases total expenditure in percent of GDP while grants increase it.

Another objection to the validity of these empirical findings is mentioned by Marlow (1988) and Joulfaian and Marlow (1990, 1991). They argue, that previous measures of government activity employ incomplete data since expenditures on the federal level are not included. The share of state expenditure (revenue) of total state and local expenditure (revenue) might be the wrong indicator because the decentralization hypothesis may still hold even if there is no significant positive relation between this variable and the size of government as long as federal government expenditure is reduced to such an extent that even an increase of state and/or bcal expenditure in a federal system are overcompensated. After including expenditure from the federal level on a disaggregated state-by-state basis they can find a significant negative correlation of the overall government size and decentralization. However, it remains unclear as to what extent state governments feel responsible for disaggregated federal expenditures since the federal budget as a whole is a common pool that has to be financed by all other states, too. Moreover, the federal government is the same for all US states. What does a dis- 
aggregation of federal expenditure and grants by states mean? It may be that in states with a more pronounced federal structure the demand for federal expenditure is - ceteris paribus lower, a result that is not necessarily supporting the Leviathan hypothesis of Brennan and $\mathrm{Bu}-$ chanan (1980). It could simply mean a shift of federal public spending from those states with a more pronounced federal structure to those with a less pronounced one, without affecting the total level. Thus, the really interesting question whether the government size of the US would be larger if it had a less pronounced federal fiscal structure remains unanswered. The results do neither support, nor contradict the proposition that countries with a federal fiscal structure have - ceteris paribus - a smaller size of the public sector.

To test the decentralization hypothesis, a cross-country analysis needs to be performed (Kirchgässner 2002b). In the spirit of Oates (1972) early study, several authors have expanded their empirical work to the country level, evaluating whether decentralized countries have smaller government sizes than centralized ones. In a cross-section analysis of 22 OECD and 39 IMF countries, Heil (1991) cannot confirm the prediction of the Brennan and Buchanan fragmentation hypothesis. On the other hand, Solano (1983) as well as Saunders (1988) and Moesen and van Cauwenberge (2000) find support for the expenditure cutting effect of federalism for some 20 OECD countries. In the latter cases the samples are, however, rather small. Because the measure of decentralization used by Moesen and van Cauwenberge (2000) is only that part of local government spending which is entirely financed by local taxes (in relation to total government spending), they nevertheless capture the degree of local fiscal independence better than earlier studies. The above-mentioned results by Jin and Zou (2002) in the case of revenue decentralization and vertical fiscal imbalance, and particularly by Rodden (2003) for the own source subnational revenue share confirm the results of Moesen and van Cauwenberge (2000) by using larger cross-country panel data sets. All of these studies focus on the competencies of subnational jurisdictions in the area of taxation and thereby establish a restrictive effect of a stronger competitive fiscal federalism on the size of government.

Another route for departure is an analysis of the different transmission channels outlined above. Fiscal decentralization implies several mechanisms that might affect government spending. The mixed empirical results on the decentralization hypothesis might as well be due to the fact that several mechanisms compensate for each other, as Sørensen (2002) argues with respect to the opposing impacts of tax competition and tax exporting. If the different effects can be identified, a much more precise picture is drawn of how fiscal decentralization affects government size. More importantly, an analysis at the national level usually has the disadvantage that the spending and taxing competencies or the degree of autonomy of sub- 
federal jurisdictions is not properly assessed. It is hence useful to conduct such an analysis for Switzerland as a country with strong fiscal competencies at the sub-federal levels.

\section{The Swiss Tax System}

Switzerland consists of three governmental layers: the central government, 26 cantons on the state level and some 3000 municipalities on the local level. The Swiss Constitution allows for comparably high fiscal competencies on the sub-federal level. All three tiers of government have their own tax sovereignty. Cantons are free to choose their taxes autonomously, except they are constitutionally reserved for the central government. The Federal Constitution explicitly lists all revenue sources of the central government in Article 42. The central government cannot levy new taxes or attract tax power from the cantons without changing the constitution which, in Switzerland, has to pass a mandatory popular referendum with a simple majority of the people as well as of the cantons. Additionally, the federal power to tax for income underlies a sunset legislation and has to be approved by voters every few years. Historically, the main taxing powers are assigned to the cantons. Even the tax harmonization law introduced in 1993 (Article 129 of the Federal Constitution) does not affect the cantonal competence with respect to tax surcharges, tax rates and tax exemptions. Cantons have the main taxing powers for individual and corporate income and property whereas the local governments levy a surcharge on the cantonal income tax and raise their own property (wealth) tax. The fiscal autonomy of municipalities varies considerably from canton to canton, but even in rather centralized cantons communes are not forced to keep tax rates on a certain level. Therefore, tax burdens vary even more among Swiss municipalities than among cantons.

Table 2 exhibits the variation of income and property taxes between the cantons for the year 2001. The index of the weighted average for Switzerland is 100 , whereas the canton Jura reaches the maximum value of 134.3 and the canton $\mathrm{Zug}$ the minimum value of 49.5. For instance, a single person who earns a gross income of 100,000 CHF is charged for 19,640 CHF income taxes on the cantonal and local level in the town of La Chaux-de-Fonds of the canton Neuchâtel. The same person living in the village of Freienbach of the canton Schwyz has to pay 4,790 CHF income taxes on the cantonal and local level only (church taxes included). The federal government relies on indirect taxes like the VAT and the mineral oil tax, but also raises a tax on income of individuals and corporations in addition to the cantons. Presently, the federal income tax covers about $60 \%$ of total federal revenue. The tax rates for the income tax on the central level are explicitly enumerated in the constitution. Currently, the statutory maximum average rate amounts for $11.5 \%$ with a maximum marginal rate of $13.2 \%$. 
Table 2: Tax burden and financial prosperity of Swiss cantons, 2001; Ratio of grants on cantonal revenue, 1999.

\begin{tabular}{|c|c|c|c|}
\hline Cantons & $\begin{array}{l}\text { Index of income } \\
\text { and property tax } \\
\text { burden }(\text { Swiss av- } \\
\text { erage }=100)\end{array}$ & $\begin{array}{c}\text { Federal index of } \\
\text { financial prosperity } \\
\text { (Swiss average }= \\
100)\end{array}$ & $\begin{array}{l}\text { Share of grants } \\
\text { from total canto- } \\
\text { nal revenues }(\%)\end{array}$ \\
\hline \multicolumn{4}{|c|}{ Financially potential cantons } \\
\hline Zug & 49.6 & 216 & 26.1 \\
\hline Basel-City & 118.9 & 173 & 10.8 \\
\hline Zurich & 82.5 & 160 & 15.1 \\
\hline Geneva & 90.2 & 141 & 9.7 \\
\hline Nidwalden & 75.5 & 129 & 39.6 \\
\hline Basel-Land & 89.6 & 120 & 15.0 \\
\hline \multicolumn{4}{|c|}{$\begin{array}{l}\text { Cantons with average financial } \\
\text { potential }\end{array}$} \\
\hline Schwyz & 65.5 & 112 & 40.4 \\
\hline Schaffhausen & 114.5 & 107 & 17.7 \\
\hline Aargau & 86.5 & 97 & 19.3 \\
\hline Vaud & 111.7 & 94 & 19.1 \\
\hline Thurgau & 110.7 & 83 & 25.7 \\
\hline Solothurn & 114 & 82 & 26.8 \\
\hline Glarus & 105.9 & 82 & 26.8 \\
\hline Ticino & 80.9 & 82 & 23.3 \\
\hline St. Gallen & 101.8 & 80 & 24.9 \\
\hline Graubünden & 95.1 & 77 & 47.1 \\
\hline Luzern & 123.7 & 67 & 27.9 \\
\hline Uri & 116.2 & 64 & 48.8 \\
\hline Appenzell a.Rh. & 108.6 & 63 & 29.6 \\
\hline Appenzell i.Rh. & 87.9 & 62 & 38.7 \\
\hline \multicolumn{4}{|c|}{ Financially weak cantons } \\
\hline Bern & 115.7 & 57 & 28.2 \\
\hline Neuchâtel & 125.5 & 55 & 38.8 \\
\hline Fribourg & 130 & 51 & 35.3 \\
\hline Obwalden & 126.7 & 35 & 44.5 \\
\hline Jura & 134.9 & 34 & 48.6 \\
\hline Valais & 125.1 & 30 & 41.7 \\
\hline Switzerland & 100 & 100 & 23.1 \\
\hline
\end{tabular}

Source: Swiss Federal Tax Administration, 2001, Swiss Federal Finance Administration, 1999

As can be seen from Table 3, the distribution of revenue and expenditure among the three layers of government changed considerably over time. Contrary to the increase in many other countries, the share of the central government in total government expenditure and revenue even decreased by about 10 percentage points within the last fifty years. Today, the financial 
importance of the sub-federal governments accounts for nearly $70 \%$ of all financial flows of the total government.

Table 3: Structure of revenue and expenditure in the Swiss federalism, 1950 - 1999

\begin{tabular}{|l|c|c|c|c|c|c|}
\hline & 1950 & 1960 & 1970 & 1980 & 1990 & 1999 \\
\cline { 2 - 7 } & $\%$ & $\%$ & $\%$ & $\%$ & $\%$ & $\%$ \\
\hline $\begin{array}{l}\text { Central gov- } \\
\text { ernment }\end{array}$ & & & & & & \\
$\begin{array}{l}\text { Revenue } \\
\text { Expenditure }\end{array}$ & 42 & 40 & 34 & 30 & 31 & 31 \\
& & 35 & 32 & 31 & 31 & 32 \\
Cantons & 32 & 33 & 39 & 39 & 39 & 40 \\
Revenue & 34 & 38 & 40 & 39 & 40 & 40 \\
Expenditure & & & & & & \\
& & & & & & \\
Municipalities & 26 & 27 & 27 & 31 & 30 & 29 \\
Revenue & 28 & 27 & 28 & 30 & 29 & 28 \\
Expenditure & 100 & 100 & 100 & 100 & 100 & 100 \\
Total* & 100 & 100 & 100 & 100 & 100 & 100 \\
Revenue & & & & & & \\
Expenditure & & & & & & \\
& & & & & & \\
\hline
\end{tabular}

* without double counting

Source: Statistical Yearbook of Switzerland, 2000, Table 18.1

All in all, with considerable tax autonomy, including progressive income and property (wealth) taxes, the Swiss sub-federal governments constitute a unique data base to investigate the effect of federalism on the size of government on the European continent. Though many other federalist countries in Europe have the power to spend, they have rather limited power to tax which in principle implies that analyzing the effect of fiscal federalism on the size of government is biased in these countries, at best.

\section{Data and Empirical Specification}

In order to test the empirical relevance of federalism on the size of government for the Swiss case, we first propose the following model:

$R_{i t}=\beta_{0}+\beta_{1} D E C_{i t}+\beta_{2} F_{R A G_{i t}}+\beta_{3}$ TAXCOMP $_{i t}+\beta_{4}$ TAXEXP $_{i t}+\beta_{5}$ GRANTS $_{i t}+\beta_{6} V_{i t}+u_{i t}(1)$

where $R_{i t}$ stands for the revenue side of the budget. More precisely, we have a closer look at real per capita revenue of the cantonal and local level as well as at the revenue categories, 
namely income, property, profit and capital tax revenue as well as user charges. As can be seen in Table 4, tax revenue accounts for about $55 \%$ of all government revenue on the cantonal and local levels. This ratio continuously diminished during the last twenty years from about $60 \%$ to $55 \%$, while the ratio of user charges on total state and local government revenue remained rather constant at about $20 \%$. Thus, other revenue sources like intergovernmental grants have gained quantitative importance during the last 20 years. Looking a bit closer on tax revenue, the numbers indicate that income taxes are by far the most important tax revenue category on the state and local levels with a ratio of more than one third of all revenue.

The model implies that public revenue is a function of revenue decentralization $\left(D E C_{i t}\right)$ the fragmentation of a jurisdiction, i.e. the competitive pressure in which the government is involved $\left(F R A G_{i t}\right)$, grants $\left(\right.$ GRANTS $\left._{i t}\right)$ which address the impact of vertical transfer payments from the central government to cantonal governments, and a vector of control variables $V_{i t}$. $\beta_{0}$ to $\beta_{6}$ are the parameters of interest while $u_{i t}$ denotes the error term. $V_{i t}$ consists of national income disaggregated to the cantonal level according to the interpretation of Wagner's Law (1892) of a possible income effect on the demand of public goods. In order to evaluate the effect of a homogenous income distribution on the size of government revenue, we introduce a variable which is constructed by the ratio of median to average income in a canton. Following Meltzer and Richard (1981), it could be hypothesized that the lower is median as compared to average income the higher the pressure to exploit the richer minority by the poorer majority in a democracy. The ratio of urban population in a canton reflects the effect of population density on fiscal policy decisions of governments. The population variable takes economies of scale into account: Can larger cantons benefit from economies of scale in order to reach a lower level of public expenditures? We thus follow the suggestions by Borcherding and Deacon (1972) for US states or Pommerehne and Frey (1976) for Swiss municipalities. A negative sign of the coefficients of these variables indicates that the larger the population the lower the level of the endogenous fiscal variables. We also include the cantonal unemployment rate and a German language dummy as controls. The impact of democracy is incorporated by an index for the extent to which direct democracy is established on the cantonal level (for a description of the Index, c.f. Stutzer and Frey (2000) and Trechsel and Serdült (1999)). According to previous empirical work (c.f. Section 3), we expect a revenue cutting effect by the instruments of direct democracy. In addition, a variable incorporating budget rules on the cantonal level is included. They can be seen as a supplementary instrument to constrain the taxing power of policymakers (Schaltegger, 2002). We also include a coalition variable in order to empirically evaluate the effect of broad based coalition governments on the exploit a- 
tion of the budget as a fiscal commons. The argument that the tax base represents a fiscal commons that will be exploited by too many spending ministers is developed by Roubini und Sachs (1989), Edin und Ohlsson (1991), Corsetti und Roubini (1992), de Haan und Sturm (1997), Kontopoulos und Perotti (1999), Velasco (1999) or Volkerink and de Haan (2001).

Table 4: Selected revenue categories on the cantonal and communal level

\begin{tabular}{|l|c|c|c|c|c|c|}
\hline \multirow{2}{*}{ Revenue categories } & 1980 & 1984 & 1988 & 1992 & 1996 & 1999 \\
\cline { 2 - 7 } & $\%$ & $\%$ & $\%$ & $\%$ & $\%$ & $\%$ \\
\hline $\begin{array}{l}\text { Total revenue } \\
\text { thereof: } \\
\text { - User charges }\end{array}$ & 100 & 100 & 100 & 100 & 100 & 100 \\
- Total tax revenue* & 61 & 62 & 61 & 58 & 55 & 54 \\
- Income and property** & 58 & 59 & 59 & 56 & 53 & 52 \\
- Income & 41 & 42 & 39 & 40 & 38 & 36 \\
- Property & 4 & 4 & 4 & 4 & 4 & 4 \\
- Profit & 6 & 6 & 7 & 6 & 5 & 6 \\
- Capital & 2 & 2 & 2 & 2 & 2 & 2 \\
\hline
\end{tabular}

Source: Swiss Federal Finance Administration, 1982, 1986, 1990, 1994, 1998, 2001

* According to the definition of the Swiss Federal Finance Administration, Total tax revenue are the sum of income and property taxes and expenditure taxes.

**According to the definition of the Swiss Federal Finance Administration, income and property taxes are the sum of income, property, profit, capital, land, property gain, property change and inheritance taxes.

The focus of the analysis is on the impact of federalism on the size of government which is tested by five different variables: revenue decentralization, fragmentation, tax competition, tax exporting and grants. Decentralization as the local fiscal autonomy is proxied by the ratio of local revenue on the aggregated state and local revenue. The fragmentation variable is constructed by the number of communes in a canton divided by population. In both cases, a negative impact on government revenue is expected. Tax competition is measured by the weighted average of the competing cantons' tax burden in the highest income tax bracket of a million Swiss francs annual taxable income. The competing cantons are all cantons except the one of consideration, weighted by the inverse of the distance (see Feld and Reulier, 2002 for a discussion of empirical studies). This variable indicates that the higher the average tax burden of the other cantons, the lower the pressure of tax competition on the cantonal and local tax authorities and the higher is tax revenue. Tax exporting is measured by the number of tourist 
nights per capita. Tax exporting possibilities relax the pressure that exit and voice exert on fiscal authorities. Tax exporting thus leads to higher tax revenue. Using this variable, we primarily capture tax exporting by the burden tourists bear especially by paying tourist fees. On the other hand, the attractiveness of a canton which is reflected in the number of tourist nights per capita might also allow for higher taxation of property owners. Finally, grants change the incentive structure for policymakers as argued in Section 2 and relax the pressure from migration to a government that overtaxes or overspends.

The analysis is performed for the revenue categories in Table 4 so that for every revenue category a corresponding variable for decentralization is constructed. With respect to the revenue structure it can be particularly expected that tax competition and tax exporting affect tax revenue categories in the predicted way instead of user charge revenue. The quantitative impact of these two variables can be expected to be the larger the more intense tax competition or the more easily taxes can be exported. An intensive tax competition might as well induce fiscal authorities to finance spending more strongly by user charges such that an increase of the average of other cantons' tax burden leads to less regard of the benefit principle.

As indicated above, a revenue restricting impact of fiscal decentralization may be the result of many different influences, among them fragmentation, tax competition and tax exporting. These three mechanisms are explicitly controlled for by the respective variables in the model. If decentralization still exerts a significant effect after the introduction of these three variables, it might well be the result of political economy influences. A decentralized competitive government structure allows for an experimentation of new public policies such that federalism works as a discovery procedure. Although other influences might be hiding in the decentralization variable, we propose that it predominantly captures the discovery hypothesis.

In order to test the hypotheses, the focus of the empirical analysis is on the aggregated state and local level. The analysis uses yearly data from 1980 to 1998 deflated to the year 1980 . The subscript $i=1, \ldots, 26$ indicates cantons and $t=1980, \ldots, 1998$ indexes years (for data description, data source and descriptive statistics, cf. Appendix A). The empirical analysis is performed using a pooled cross-section time-series model. We follow Feld and Kirchgässner (2001), who argue that despite the panel structure of the data the inclusion of fixed effects in the cross-section domain is inappropriate because the institutional variables reflecting the extent of federalism vary only very little or remain constant over time in a few cantons. Accordingly, cantonal intercepts do not make sense as the captured impact on fiscal outcomes is either solely driven by the time variation or in case of time invariant variables, fixed effects 
are likely to hide the effect of institutional variables and render them insignificant. The consistency of OLS-estimates depends on the exogeneity of the regressands. In order to tackle the problem of possible endogeneity of the decentralization variable, we use an instrumental variable technique with lags $t-1$ of the original decentralization as well as spatial lags of all regressands as instruments for the tax competition variable. Finally, year effects to circumvent time dependency are included and the standard errors are corrected by the clustering method.

\section{Results}

The test strategy is first estimating the model with the decentralization and grants variables and second, additionally including the three specific mechanisms by which federalism affects government size. The overall results in Table 5 indicate that fiscally more decentralized cantons have smaller governments measured by public revenue as predicted by the decentralization hypothesis. This is true for total government revenue and for tax revenue but not for user charges. Looking at the tax revenue categories, some interesting differences can be distinguished as well. Taxes on income are significantly reduced under revenue decentralization whereas taxes on property and wealth are not touched by differences in the assignment of taxes between the cantonal and the communal level. Taxes on income and property as a whole are negatively affected by fiscal decentralization as well. Interestingly, decentralizing corporate taxes leads to less capital taxes while taxes on profits are not significantly reduced. All in all, the obtained results show that fiscal decentralization favors a smaller size of government revenue in Switzerland as predicted by Oates (1972) and Brennan and Buchanan (1980).

Introducing fragmentation, tax competition and tax exporting, the effect of fiscal decentralization is reduced in magnitude but exhibits the same structure of effects. Still there is no significant impact of revenue decentralization on revenue from user charges, on property and profit tax revenue. The statistical significances of the decentralization impacts are increased however such that the estimated effects appear to be more precisely estimated. Controlling for fragmentation, tax exporting and competition, the remaining effect of decentralization mainly appears to capture political economy effects as the one summarized in the discovery hypothesis. Decentralized decision-making keeps government revenue low. The fragmentation hypothesis does not seem to be relevant in the Swiss case since the estimation results exhibit insignificant results. Only with respect to the tax structure two notable effects can be found: Tax revenue from income taxes is negatively affected by fragmentation though only marginally significant while capital tax revenue is significantly positively influenced. 


\begin{tabular}{|c|c|c|c|c|c|c|c|c|c|c|c|c|c|c|c|c|}
\hline \multicolumn{17}{|c|}{ Table 5: TSLS estimates for government size, revenue structure, 26 Swiss cantons, 1980-1998 } \\
\hline \multirow{2}{*}{$\begin{array}{l}\text { Variable } \\
\text { Decentralization }\end{array}$} & \multicolumn{2}{|c|}{ Total revenue } & \multicolumn{2}{|c|}{ Tax revenue } & \multicolumn{2}{|c|}{ User Charges } & \multicolumn{2}{|c|}{$\begin{array}{l}\text { Tax on income and } \\
\text { property }\end{array}$} & \multicolumn{2}{|c|}{$\begin{array}{l}\text { Tax on property } \\
\quad \text { (wealth) }\end{array}$} & \multicolumn{2}{|c|}{ Tax on income } & \multicolumn{2}{|c|}{ Tax on profits } & \multicolumn{2}{|c|}{ Tax on capital } \\
\hline & $\begin{array}{l}-0.423^{* *} \\
(-2.33)\end{array}$ & $\begin{array}{l}-0.390 * * \\
(-2.67)\end{array}$ & $\begin{array}{l}-0.153 * * \\
(2.42)\end{array}$ & $\begin{array}{l}-0.137 * * * \\
(-3.26)\end{array}$ & $\begin{array}{l}0.183 \\
(1.29)\end{array}$ & $\begin{array}{l}0.196 \\
(1.41)\end{array}$ & $\begin{array}{l}-0.439 * * * \\
(-3.14)\end{array}$ & $\begin{array}{l}-0.396^{* * *} \\
(4.20)\end{array}$ & $\begin{array}{l}-0.209 \\
(-0.90)\end{array}$ & $\begin{array}{l}0.012 \\
(0.04)\end{array}$ & $\begin{array}{l}-0.662 * * * \\
(-3.24)\end{array}$ & $\begin{array}{l}-0.611^{* * * *} \\
(-4.35)\end{array}$ & $\begin{array}{l}-0.116 \\
(-0.45)\end{array}$ & $\begin{array}{l}-0.172 \\
(-0.62)\end{array}$ & $\begin{array}{l}-0.861 * * \\
(-2.42)\end{array}$ & $\begin{array}{l}-0.988 * * * \\
(-3.72)\end{array}$ \\
\hline Fragmentation & & $\begin{array}{l}12.530 \\
(0.25)\end{array}$ & & $\begin{array}{l}19.416 \\
(0.30)\end{array}$ & & $\begin{array}{l}85.332 \\
(0.95)\end{array}$ & & $\begin{array}{l}24.473 \\
(0.44)\end{array}$ & & $\begin{array}{l}38.181 \\
(0.32)\end{array}$ & & $\begin{array}{l}-125.400 \\
(-1.65)\end{array}$ & & $\begin{array}{l}137.383 \\
(0.69)\end{array}$ & & $\begin{array}{l}620.078 \text { *** } \\
(5.15)\end{array}$ \\
\hline Tax competition & & $\begin{array}{l}0.052 * * * \\
(3.32)\end{array}$ & & $\begin{array}{l}0.020^{*} \\
(1.78)\end{array}$ & & $\begin{array}{l}0.011 \\
(0.56)\end{array}$ & & $\begin{array}{l}0.020^{*} \\
(1.86)\end{array}$ & & $\begin{array}{l}0.060 * * \\
(2.43)\end{array}$ & & $\begin{array}{l}0.031^{* *} \\
(2.55)\end{array}$ & & $\begin{array}{l}-0.017 \\
(-0.38)\end{array}$ & & $\begin{array}{l}-0.045 \\
(-1.59)\end{array}$ \\
\hline Tax exporting & & $\begin{array}{l}0.013 \\
(1.25)\end{array}$ & & $\begin{array}{l}0.069^{* * * *} \\
(3.48)\end{array}$ & & $\begin{array}{l}0.064 * * * \\
(2.83)\end{array}$ & & $\begin{array}{l}0.055^{* * * *} \\
(3.24)\end{array}$ & & $\begin{array}{l}0.182 * * * \\
(3.73)\end{array}$ & & $\begin{array}{l}0.021 \\
(0.82)\end{array}$ & & $\begin{array}{l}0.089 \\
(1.39)\end{array}$ & & $\begin{array}{l}0.211 \text { *** } \\
(4.07)\end{array}$ \\
\hline Grants & $\begin{array}{l}0.250^{* * * *} \\
(4.86)\end{array}$ & $\begin{array}{l}0.212 * * * \\
(6.59)\end{array}$ & $\begin{array}{l}-0.041 \\
(-0.87)\end{array}$ & $\begin{array}{l}-0.092^{* *} \\
(-2.53)\end{array}$ & $\begin{array}{l}0.162^{* *} \\
(2.03)\end{array}$ & $\begin{array}{l}0.095 \\
(1.53)\end{array}$ & $\begin{array}{l}-0.062 \\
(-1.41)\end{array}$ & $\begin{array}{l}-0.099 * * * \\
(-3.08)\end{array}$ & $\begin{array}{l}0.070 \\
(0.68)\end{array}$ & $\begin{array}{l}-0.048 \\
(-0.48)\end{array}$ & $\begin{array}{l}-0.104 * * \\
(-2.45)\end{array}$ & $\begin{array}{l}-0.073 \\
(-1.67)\end{array}$ & $\begin{array}{l}-0.152 \\
(-1.16)\end{array}$ & $\begin{array}{l}-0.277 * * \\
(-2.55)\end{array}$ & $\begin{array}{l}0.262 \\
(1.44)\end{array}$ & $\begin{array}{l}0.085 \\
(-0.89)\end{array}$ \\
\hline Democracy & $\begin{array}{l}-0.141^{*} \\
(-1.94)\end{array}$ & $\begin{array}{l}-0.152 \\
(-1.54)\end{array}$ & $\begin{array}{l}0.293 * * * \\
(-2.88)\end{array}$ & $\begin{array}{l}-0.319 * * \\
(-2.77)\end{array}$ & $\begin{array}{l}-0.562 \\
(-0.38)\end{array}$ & $\begin{array}{l}-0.069 \\
(-0.43)\end{array}$ & $\begin{array}{l}-0.258^{* *} \\
(2.58)\end{array}$ & $\begin{array}{l}-0.309 * * * \\
(-2.91)\end{array}$ & $\begin{array}{l}-0.578 \text { *** } \\
(-2.92)\end{array}$ & $\begin{array}{l}-0.693 * * * \\
(-4.00)\end{array}$ & $\begin{array}{l}-0.161 \\
(-1.11)\end{array}$ & $\begin{array}{l}-0.262^{*} \\
(-1.89)\end{array}$ & $\begin{array}{l}-0.596^{*} \\
(-1.76)\end{array}$ & $\begin{array}{l}-0.424 \\
(-1.44)\end{array}$ & $\begin{array}{l}0.077 \\
(0.21)\end{array}$ & $\begin{array}{l}0.416^{*} \\
(1.98)\end{array}$ \\
\hline Budget rule & $\begin{array}{l}-0.011 \\
(-0.42)\end{array}$ & $\begin{array}{l}-0.006 \\
(-0.29)\end{array}$ & $\begin{array}{l}-0.014 \\
(-0.43)\end{array}$ & $\begin{array}{l}-0.010 \\
(-0.39)\end{array}$ & $\begin{array}{l}0.016 \\
(0.70)\end{array}$ & $\begin{array}{l}0.022 \\
(0.60)\end{array}$ & $\begin{array}{l}-0.016 \\
(-0.49)\end{array}$ & $\begin{array}{l}-0.0169 \\
(-0.68)\end{array}$ & $\begin{array}{l}-0.331 \\
(-1.14)\end{array}$ & $\begin{array}{l}-0.030 \\
(-0.55)\end{array}$ & $\begin{array}{l}-0.011 \\
(-0.34)\end{array}$ & $\begin{array}{l}-0.023 \\
(-0.82)\end{array}$ & $\begin{array}{l}-0.042 \\
(-0.52)\end{array}$ & $\begin{array}{l}-0.011 \\
(-0.15)\end{array}$ & $\begin{array}{l}-0.096 \\
(-1.23)\end{array}$ & $\begin{array}{l}-0.037 \\
(-0.47)\end{array}$ \\
\hline Coalition & $\begin{array}{l}0.028^{*} \\
(1.97)\end{array}$ & $\begin{array}{l}0.042^{* *} \\
(2.70)\end{array}$ & $\begin{array}{l}-0.006 \\
(-0.35)\end{array}$ & $\begin{array}{l}0.012 \\
(0.57)\end{array}$ & $\begin{array}{l}0.088 * * * \\
(2.90)\end{array}$ & $\begin{array}{l}0.094 * * * \\
(3.65)\end{array}$ & $\begin{array}{l}-0.014 \\
(-1.08)\end{array}$ & $\begin{array}{l}-0.001 \\
(-0.03)\end{array}$ & $\begin{array}{l}0.044 \\
(0.75)\end{array}$ & $\begin{array}{l}0.099 \\
(1.64)\end{array}$ & $\begin{array}{l}-0.007 \\
(-0.30)\end{array}$ & $\begin{array}{l}0.016 \\
(0.64)\end{array}$ & $\begin{array}{l}-0.109 * * \\
(2.52)\end{array}$ & $\begin{array}{l}-0.102 * * \\
(-2.32)\end{array}$ & $\begin{array}{l}-0.106 \\
(-1.66)\end{array}$ & $\begin{array}{l}-0.128^{*} \\
(-1.82)\end{array}$ \\
\hline Cantonal income & $\begin{array}{l}0.296 * * \\
(2.13)\end{array}$ & $\begin{array}{l}0.280^{* *} \\
(2.59)\end{array}$ & $\begin{array}{l}0.405^{* * * *} \\
(2.94)\end{array}$ & $\begin{array}{l}0.385^{* * *} \\
(4.00)\end{array}$ & $\begin{array}{l}0.116 \\
(0.48)\end{array}$ & $\begin{array}{l}0.113 \\
(0.55)\end{array}$ & $\begin{array}{l}0.399 * * * \\
(3.28)\end{array}$ & $\begin{array}{l}0.383 * * * \\
(4.44)\end{array}$ & $\begin{array}{l}0.474 \\
(1.67)\end{array}$ & $\begin{array}{l}0.442 \\
(1.35)\end{array}$ & $\begin{array}{l}-0.010 \\
(-0.05)\end{array}$ & $\begin{array}{l}-0.055 \\
(-0.38)\end{array}$ & $\begin{array}{l}1.984 * * * \\
(9.33)\end{array}$ & $\begin{array}{l}2.001 * * * \\
(9.05)\end{array}$ & $\begin{array}{l}2.404 * * * \\
(7.64)\end{array}$ & $\begin{array}{l}2.506 * * * \\
(7.90)\end{array}$ \\
\hline Homogeneity & $\begin{array}{l}0.169 \\
(1.67)\end{array}$ & $\begin{array}{l}0.147 \\
(1.65)\end{array}$ & $\begin{array}{l}0.156 \\
(1.34)\end{array}$ & $\begin{array}{l}0.120 \\
(1.21)\end{array}$ & $\begin{array}{l}0.150 \\
(0.89)\end{array}$ & $\begin{array}{l}0.114 \\
(0.73)\end{array}$ & $\begin{array}{l}0.102 \\
(0.88)\end{array}$ & $\begin{array}{l}0.063 \\
(0.66)\end{array}$ & $\begin{array}{l}0.051 \\
(0.19)\end{array}$ & $\begin{array}{l}-0.006 \\
(-0.02)\end{array}$ & $\begin{array}{l}0.167 \\
(1.01)\end{array}$ & $\begin{array}{l}0.120 \\
(1.01)\end{array}$ & $\begin{array}{l}-0.167 \\
(-0.67)\end{array}$ & $\begin{array}{l}-0.141 \\
(-0.40)\end{array}$ & $\begin{array}{l}-0.389 \\
(-1.05)\end{array}$ & $\begin{array}{l}-0.383 \\
(-1.65)\end{array}$ \\
\hline Population & $\begin{array}{l}0.028 \\
(1.49)\end{array}$ & $\begin{array}{l}-0.039 \\
(-1.59)\end{array}$ & $\begin{array}{l}0.003 \\
(0.14)\end{array}$ & $\begin{array}{l}-0.086 * * * \\
(-3.21)\end{array}$ & $\begin{array}{l}0.006 \\
(0.17)\end{array}$ & $\begin{array}{l}-0.082 * * \\
(-2.37)\end{array}$ & $\begin{array}{l}0.011 \\
(0.59)\end{array}$ & $\begin{array}{l}-0.063 * * * \\
(-2.84)\end{array}$ & $\begin{array}{l}-0.775 \\
(-1.14)\end{array}$ & $\begin{array}{l}-0.320 * * * \\
(-3.64)\end{array}$ & $\begin{array}{l}0.021 \\
(0.80)\end{array}$ & $\begin{array}{l}-0.004 \\
(-0.11)\end{array}$ & $\begin{array}{l}-0.055 \\
(-0.81)\end{array}$ & $\begin{array}{l}-0.166^{*} \\
(-2.04)\end{array}$ & $\begin{array}{l}0.122 \\
(1.50)\end{array}$ & $\begin{array}{l}-0.161 \\
(-1.45)\end{array}$ \\
\hline Urban & $\begin{array}{l}0.284 * * * \\
(3.77)\end{array}$ & $\begin{array}{l}0.280^{* * * *} \\
(4.02)\end{array}$ & $\begin{array}{l}0.384^{* * * *} \\
(4.34)\end{array}$ & $\begin{array}{l}0.370^{* * * *} \\
(5.32)\end{array}$ & $\begin{array}{l}0.445^{* *} \\
(2.31)\end{array}$ & $\begin{array}{l}0.501 * * \\
(2.67)\end{array}$ & $\begin{array}{l}0.372 * * * \\
(4.07)\end{array}$ & $\begin{array}{l}0.356^{* * * *} \\
(5.16)\end{array}$ & $\begin{array}{l}0.393 \\
(1.70)\end{array}$ & $\begin{array}{l}0.363 \\
(1.19)\end{array}$ & $\begin{array}{l}0.292 * * * \\
(2.82)\end{array}$ & $\begin{array}{l}0.120 \\
(1.24)\end{array}$ & $\begin{array}{l}0.366 \\
(1.18)\end{array}$ & $\begin{array}{l}0.552 \\
(1.57)\end{array}$ & $\begin{array}{l}-0.068 \\
(-0.20)\end{array}$ & $\begin{array}{l}0.598^{*} \\
(1.76)\end{array}$ \\
\hline Unemployment & $\begin{array}{l}0.015 \\
(1.04)\end{array}$ & $\begin{array}{l}0.020 \\
(1.52)\end{array}$ & $\begin{array}{l}0.007 \\
(0.52)\end{array}$ & $\begin{array}{l}0.013 \\
(0.98)\end{array}$ & $\begin{array}{l}0.021 \\
(0.73)\end{array}$ & $\begin{array}{l}0.032 \\
(1.10)\end{array}$ & $\begin{array}{l}0.005 \\
(0.32)\end{array}$ & $\begin{array}{l}0.008 \\
(0.58)\end{array}$ & $\begin{array}{l}-0.027 \\
(0.87)\end{array}$ & $\begin{array}{l}-0.016 \\
(-0.46)\end{array}$ & $\begin{array}{l}0.012 \\
(0.70)\end{array}$ & $\begin{array}{l}-0.001 \\
(-0.06)\end{array}$ & $\begin{array}{l}0.024 \\
(0.70)\end{array}$ & $\begin{array}{l}0.051 \\
(1.32)\end{array}$ & $\begin{array}{l}-0.015 \\
(-0.33)\end{array}$ & $\begin{array}{l}0.064^{*} \\
(1.85)\end{array}$ \\
\hline $\begin{array}{l}\text { German } \\
\text { language }\end{array}$ & $\begin{array}{l}0.078 \\
(1.56)\end{array}$ & $\begin{array}{l}0.117 \\
(1.43)\end{array}$ & $\begin{array}{l}0.020 \\
(0.31)\end{array}$ & $\begin{array}{l}0.085 \\
(0.93)\end{array}$ & $\begin{array}{l}0.226^{*} \\
(1.94)\end{array}$ & $\begin{array}{l}0.284 * * \\
(20.5)\end{array}$ & $\begin{array}{l}-0.024 \\
(-0.42)\end{array}$ & $\begin{array}{l}0.061 \\
(0.80)\end{array}$ & $\begin{array}{l}0.473 * * \\
(2.81)\end{array}$ & $\begin{array}{l}0.683 * * * \\
(4.24)\end{array}$ & $\begin{array}{l}-0.000 \\
(-0.00)\end{array}$ & $\begin{array}{l}0.098 \\
(1.04)\end{array}$ & $\begin{array}{l}0.091 \\
(0.47)\end{array}$ & $\begin{array}{l}-0.0224 \\
(-0.09)\end{array}$ & $\begin{array}{l}-0.260 \\
(-1.06)\end{array}$ & $\begin{array}{l}-0.408 * * \\
(-2.25)\end{array}$ \\
\hline Year effects & Yes & Yes & Yes & Yes & Yes & Yes & Yes & Yes & Yes & Yes & Yes & Yes & Yes & Yes & Yes & Yes \\
\hline $\begin{array}{l}\text { Observations } \\
\mathrm{R}^{2} \\
\text { Jarque-Bera } \\
\text { Note: } \\
\text { Government size } \\
\text { levels, respective } \\
\text { decentralization, }\end{array}$ & $\begin{array}{l}494 \\
0.827 \\
7.626^{* *} \\
\\
\text { tands for st }\end{array}$ & $\begin{array}{l}494 \\
0.866 \\
0.195\end{array}$ & $\begin{array}{l}494 \\
0.836 \\
2.662\end{array}$ & $\begin{array}{l}494 \\
0.882 \\
0.191\end{array}$ & $\begin{array}{l}494 \\
0.576 \\
11.027 \text { *** }\end{array}$ & $\begin{array}{l}494 \\
0.615 \\
3.448\end{array}$ & $\begin{array}{l}494 \\
0.867 \\
1.813\end{array}$ & $\begin{array}{l}494 \\
0.902 \\
0.382\end{array}$ & $\begin{array}{l}494 \\
0.563 \\
17.552 * * *\end{array}$ & $\begin{array}{l}494 \\
0.559 \\
7.869 * *\end{array}$ & $\begin{array}{l}494 \\
0.778 \\
10.167 * * *\end{array}$ & $\begin{array}{l}494 \\
0.840 \\
4.206\end{array}$ & $\begin{array}{l}494 \\
0.737 \\
1.600\end{array}$ & $\begin{array}{l}494 \\
0.750 \\
0.039\end{array}$ & $\begin{array}{l}494 \\
0.671 \\
26.165^{* * *}\end{array}$ & $\begin{array}{l}494 \\
0.793 \\
4.414\end{array}$ \\
\hline
\end{tabular}


The tax competition variable exhibits the expected positive sign indicating that a higher average tax burden of competing cantons relaxes the competitive pressure on cantonal fiscal authorities. Tax competition does however not have a statistically significant effect on user charges and only a marginally significant impact on tax revenue on the 10 percent level. Looking at the tax structure, it becomes obvious that tax competition is the most restrictive in the case of income and property (wealth) tax revenues, but does not have any effect on profit and capital tax revenues. Hence the tax competition hypothesis cannot be rejected according to these results. Tax exporting on the other hand has a strong influence on several revenue categories. Tax exporting possibilities increase government revenue in the case of tax revenue, user charges and taxes on income and property in general. From single tax revenue components, property and capital taxes appear to be positively affected while income and profits taxes are not. These results are in line with the hypotheses formulated above. In the case of user charges, exporting of financial burden to tourists is possible in a similar fashion as in the case of indirect taxes. Hence, the competitive pressure on cantonal governments is reduced and revenue from user charges increases. On the other hand, cantons that are attractive to tourists enable the government to exploit property and capital owners to a larger extent. The attractiveness of the area is positively capitalized in property (wealth) and capital taxes.

The grants variable is positive and significant for general revenue, but negative for tax revenue. This is reasonable since grants are one source of income for the sub-national governments, enabling them to reduce the tax burden for their constituency without being forced to reduce government spending as well. This strategy is especially attractive for politicians in the case of income and property as well as profit taxes.

Thus, the effect of federalism on the size of government in Switzerland stems from decentralization and the fiscal autonomy of sub-federal governments in the possibility of deciding about tax instruments on their own and the resulting tax competition, but not from the competitive pressure of having many governmental units. Tax competition is effectively restric ting the government in the case of income and property (wealth) taxes. Tax exporting partly compensates the revenue reducing effect of tax competition and leads to higher tax revenue, but does not suffice to compensate the revenue restriction imposed by tax competition with respect to total revenue. Though fragmentation empirically has not proven to be a significant determinant explaining the size of government revenue, it has to be noted that it is to some extent a precondition for fiscal decentralization. Thus, it might be that fragmentation has an indirect effect on the size of government revenue. The impact of decentralization on govern- 
ment size may additionally stem from the cost saving decentralized experimentation of new government policies.

Looking at the democracy variable, we obtain similar results as for the decentralization variable. The stronger popular rights in a canton the smaller the revenue burden voters have to bear. In contrast to decentralization, direct popular rights mainly reduce income and property (wealth) taxes but not profit taxes. The overall results are in line with those reported by Feld and Kirchgässner (2001) and Feld and Matsusaka (2002). Interestingly, budget rules have essentially no effect on state and local tax revenues in Switzerland. However, as shown by Schaltegger (2002), statutory requirements in the cantons reduce cantonal spending as well as budget deficits. As can be seen by the results in Table 5, the hypothesis of broad based coalition governments that tend to exploit the fiscal resources finds support for total government revenue. This finding is consistent with those found by Volkerink and de Haan (2001) for OECD-countries. For tax revenue we cannot find support for the coalition hypothesis with respect to the case of Swiss sub-federal governments implying that broad based coalition go vernments tend to expand government revenue by raising user charges.

Wagner's Law becomes confirmed for the revenue structure as a whole by the positive and significant impact of cantonal income on the revenue measures. User charges are however not correlated with income. The homogeneity of income distribution and unemployment have no effect on the size of the government. The results for the variable population are inconclusive but the share of urban population in a canton has a positive and significant impact on the whole revenue structure implying possible agglomeration effects in urban areas which promote economic activity and thus favor higher government revenue. Unemployment does not have a significant effect of cantonal revenue. The language variable is only significant in the case of user charges and property taxes.

As we observe different effects of federalism on the size of tax revenue as compared to the size of user charges, a natural question occurs in this context: What is the effect of federalism on the distribution between taxes and user charges? It could be argued that decentralization strengthens the benefit principle where consumers are more likely to be confronted with marginal costs of their decisions (Wicksell, 1896). Thus, decentralization might favor governments to rely more on user charges and less on taxes. If this were true, decentralization should have a negative effect on the ratio of tax revenue on total revenue. In order to conduct a formal test we regress log-odds of the tax revenue ratio on the regressands of equation (1). 
Table 6: TSLS Log-odds estimates for the tax ratio of total government revenue, 26 Swiss cantons, 1980-1998

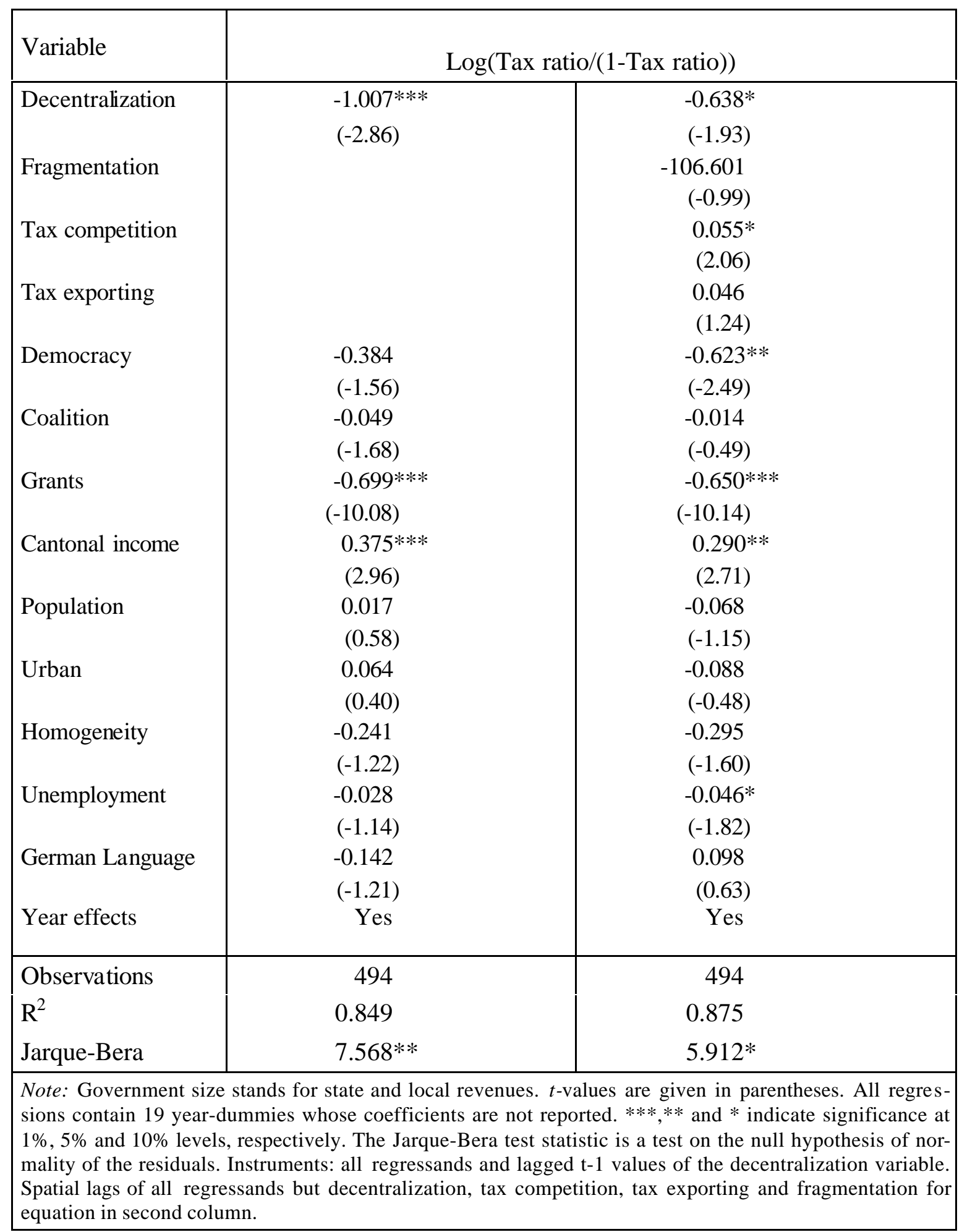

As can be seen from Table 6, decentralization in fact favors a smaller ratio of tax revenue on total government revenue. Thus, the hypothesis, that decentralization strengthens the benefit principle between government spending and government revenue cannot be rejected according to the results obtained for the Swiss state and local level. It also remains significantly 
negative if the three transmission mechanisms, fragmentation, tax competition and tax exporting, are included in the regression. From the specific mechanisms only tax competition has a significant impact. The more favorable the position of a canton is in the tax competition with other cantons the more the canton relies on taxes instead of user charges. The fragmentation and tax exporting variables have only a weak explanatory power for the tax share of total government revenue. Interestingly, direct democracy has the same effect as decentralization in the presented results which supports findings by Feld and Matsusaka (2002).

All in all, the results for the Swiss federalism indicate that revenue decentralization favors a smaller size of government revenue. This especially holds for tax revenue but not for user charges. Moreover, decentralization favors a shift of revenue instruments of the government from taxes to user charges. Tax competition tends to restrict the taxation of income and property while tax exporting relaxes the pressure on fiscal authorities. The remaining negative effect of decentralization on government revenue is conjectured to be due to political economy reasons.

\section{Conclusions}

The purpose of this paper is to test the effect of federalism on the size of government. As a survey on the empirical literature shows, up to now many authors have been concerned with the evaluation of the validity of the Leviathan-hypothesis arguing that constitutional restrictions like federalism strengthen political competition and therefore lead to a smaller size of government. The overall results are not conclusive even though supportive studies have recently gained more attention. However, most studies are performed in a US context.

This study uses data from Switzerland to evaluate the question of federalism and its impact on the size of government. Swiss federalism allows for a far reaching fiscal autonomy on the revenue side of the budget for sub-national governments and therefore represents a unique data base to investigate the Leviathan-hypothesis within Europe. The present work suggests that federalism measured by revenue decentralization has a strong revenue cutting effect. This is true for general revenue for cantons and municipalities as well as for most revenue categories. An interesting exception concerns user charges. Decentralization appears to restrict the government's taxing abilities mainly by tax competition and political economy mechanisms. Tax exporting only partially reduces the pressure on the fisc. A natural question that emerges in this context is whether federalism would strengthen the benefit principle of government spending and revenue. Thus, we test the impact of federalism on the ratio of tax revenue from total government revenue as well. The results show that decentralization in fact leads to a sig- 
nificant smaller ratio of tax revenue on total government revenue implying that user charges play a more prominent role in financing government activity in a competitive federalism.

\section{References}

Borcherding, T.E. and R.T. Deacon (1972), The Demand for the Services of Non-Federal Governments, American Economic Review 62, 891-901.

Brennan, G. and J.M. Buchanan (1977), Towards a Tax Constitution for Leviathan, Journal of Public Economics 8, 255-273.

Brennan, G. and J.M. Buchanan (1978), Tax Instruments as Constraints on the Disposition of Public Revenues, Journal of Public Economics 9, 301-318.

Brennan, G. and J.M. Buchanan (1980), The Power to Tax: Analytical Foundations of a Fiscal Constitution, Cambridge, Cambridge University Press.

Corsetti, G. and N. Roubini (1992), Tax Smoothing Discretion Versus Balanced Budget Rules in the Presence of Politically Motivated Deficits: The Design of Optimal Fiscal Rules for Europe after 1992, CEPR Discussion Paper No. 682.

De Haan, J. and J.-E. Sturm (1997), Political and Economic Determinants of Budget Deficits and Government Spending: A Reinvestigation, European Journal of Political Economy 13, 739-750.

DiLorenzo, T.J. (1983), Economic Competition and Political Competition: An Empirical Note, Public Choice 40, 203-209.

Eberts, R.W. and T.J. Gronberg (1988), Can Competition among Local Governments Constrain Government Spending?, Federal Reserve Bank of Cleveland Economic Review 1, 2-9.

Edin, P.-A. and H. Ohlsson (1991), Political Determinants of Budget Deficits: Coalition Effects Versus Minority Effects, European Economic Review 35, 1597-1603.

Epple, D. and A. Zelenitz (1981), The Implication of Competition among Jurisdictions: Does Tiebout Need Politics?, Journal of Political Economy 89, 1197-1217.

Feld, L.P. and G. Kirchgässner (2001), The Political Economy of Direct Legislation: Is There a Role of Direct Democracy in EU Decision-Making?, Economic Policy 33, 329-367.

Feld, L.P. and J.G. Matsusaka (2002), The Political Economy of Tax Structure: Some Panel Evidence for Swiss Cantons, mimeo, Philipps-University of Marburg.

Feld, L.P. and E. Reulier (2002), Strategic Tax Competition in Switzerland: Evidence from a Panel of the Swiss Cantons, Unpublished Manuscript, University of St. Gallen 2002.

Forbes, K.F. and E.M. Zampelli (1989), Is Leviathan a Mythical Beast?, American Economic Review $79,568-577$.

Grossman, P.J. (1989), Fiscal Decentralization and Government Size: An Extension, Public Choice 62, 63-69.

Grossman, P.J. and E.G. West (1994), Federalism and the Growth of Government Revisited, Public Choice 79: 19-32.

Heil, J.B. (1991), The Search for Leviathan Revisted, Public Finance Quarterly 19, 334-346.

Hettich, W. and S.L. Winer (1988), Economic and Political Foundations of Tax Structure, American Economic Review 78, 701-712.

Hettich, W. and S.L. Winer (1997), The Political Economy of Taxation, in: D.C. Mueller (ed.), Perspectives on Public Choice, Cambridge, Cambridge University Press, 481-505.

Hines, J.R. and R.H. Thaler (1995), Anomalies: The Flypaper Effect, Journal of Economic Perspectives $9,217-226$. 
Hirschman, A.O. (1970), Exit, Voice and Loyalty: Responses to Decline in Firms, Organisations and States. Cambridge, Harvard University Press.

Jin, J. and H. Zou (2002), How Does Fiscal Decentralization Affect Aggregate, National, and Subnational Government Size?, Journal of Urban Economics 52, 270-293.

Jones, M.P, P. Sanguinetti and T. Tommasi (1999), Politics, Institutions, and Public Sector Spending in the Argentine Provinces, in: J. Poterba and J. von Hagen (eds.), Fiscal Institutions and Fiscal Performance, Chicago, Chicago University Press, 135-150.

Joulfaian, D. and M.L. Marlow (1990), Government Size and Centralization: Evidence from Disaggregated Data, Southern Economic Journal 56, 1094-1102.

Joulfaian, D. and M.L. Marlow (1991), Centralization and Government Competition, Applied Economics 23, 1603-1612.

Keen, M.J. and C. Kotsogiannis (2002), Does Federalism Lead to Excessively High Taxes?, American Economic Review 92, 363-369.

Kirchgässner, G. (2002a), Föderalismus und Staatsquote, in: U. Wagschal and H. Rentsch (eds.), Der Preis des Föderalismus, Zürich, Orell Füssli, 71-91.

Kirchgässner, G. (2002b), The Effects of Fiscal Institutions on Public Finance: A Survey of the Empirical Evidence, in: S.L. Winer and H. Shibata (eds.), Political Economy and Public Finance: The Role of Political Economy in the Theory and Practice of Public Economics, Cheltenham, Edward Elgar, 145-177.

Kontopoulos, Y. and R. Perotti (1999), Government Fragmentation and Fiscal Policy Outcomes: Evidence from OECD Countries, in: J.M. Poterba and J. von Hagen (eds.), Fiscal Institutions and Fiscal Performance, Chicago, Chicago University Press, 81-102.

Marlow, M.L. (1988), Fiscal Decentralization and Government Size, Public Choice 56, 259-269.

Matsusaka, J.G. (1995), Fiscal Effects of the Voter Initiative: Evidence from the Last 30 Years, Journal of Political Economy 103, 587-623.

McLure, C.E. (1967), The Interstate Exporting of State and Local Taxes: Estimates for 1962, National Tax Journal 20, 49-77.

Meltzer, A.H. and S. Richard (1981), A Rational Theory of the Size of Government, Journal of Political Economy 89, 914-927.

Meltzer, A.H. and S.F. Richard (1983), Tests of a Rational Theory of the Size of Government, Public Choice 41, 403-418.

Moesen W. and Ph. van Cauwenberge (2000), The Status of the Budget Constraint, Federalism and the Relative Size of Government: A Bureaucratic Approach, Public Choice 104, 207-224.

Nelson, M.A. (1986), An Empirical Analysis of State and Local Government Tax Structures in the Context of the Leviathan Model of Government, Public Choice 49, 283-294.

Nelson, M.A. (1987), Searching for Leviathan: Comment and Extension, American Economic Review 77, 198-204.

Oates, W.E. (1972), Fiscal Federalism, New York, Harcourt Brace Jovanovich.

Oates, W.E. (1985), Searching for Leviathan: An Empirical Study, American Economic Review 75, 748-757.

Oates, W.E (1999), An Essay on Fiscal Federalism, Journal of Economic Literature 37, 1120-1149.

Olson, M. (1982), The Rise and Decline of Nations: Economic Growth, Stagflation, and Social Rigidities, New Haven/London, Yale University Press,.

Persson, T. and G. Tabellini (1994), Does Centralization Increase the Size of Government?, European Economic Review 38, 765-773. 
Persson, T. and G. Tabellini (2000), Political Economics: Explaining Economic Policy, London, MIT Press.

Pommerehne, W.W. and B.S. Frey (1976), Two Approaches to Estimating Public Expenditure, Public Finance Quarterly 4, 395-407.

Qian, Y. and G. Roland (1998), Federalism and Soft Budget Constraint, American Economic Review 88, 1143-1162.

Raimondo, H.J. (1989), Leviathan and Federalism in the United States, Public Finance Quarterly 17, 204-215.

Roberts, K.W.S. (1977), Voting over Income Tax Schedules, Journal of Public Economics 8, 329-340.

Rodden, J. (2002), The Dilemma of Fiscal Federalism: Grants and Fiscal Performance Around the World, American Journal of Political Science 46, 670-687.

Rodden, J. (2003), Reviving Leviathan: Fiscal Federalism and the Growth of Government, mimeo, Department of Political Science, MIT, Cambridge.

Romer, T. (1975), Individual Welfare, Majority Voting, and the Properties of a Linear Income Tax, Journal of Public Economics 4, 163-185.

Roubini, N. and J.D. Sachs (1989), Political and Economic Determinants of Budget Deficits in the Industrial Democracies, European Economic Review 33, 903-938.

Saunders, P. (1988), Explaining International Differences in Public Expenditure: An Empirical Study, Public Finance/Finances Publiques 43, 273-294.

Schaltegger, C.A. (2001), The Effects of Federalism and Democracy: Evidence from Swiss Subnational Jurisdictions, ifo-Studien 47, 145-162.

Schaltegger, C.A. (2002), Budgetregeln und ihre Wirkung auf die öffentlichen Haushalte: Empirische Ergebnisse aus den US-Bundesstaaten und den Schweizer Kantonen, Schmollers Jahrbuch 122, 369-413.

Schneider, M. (1986), Fragmentation and the Growth of Local Government, Public Choice 48, 25563.

Schnellenbach, J. (2003), Dezentrale Finanzpolitik und Modellunsicherheit: Eine theoretische Untersuchung zur Rolle des fiskalischen Wettbewerbs als Wissen generierender Prozess, Ph.D.-Thesis, University of St. Gallen.

Shadbegian, R.J. (1999), Fiscal Federalism, Collusion, and Government Size: Evidence from the States, Public Finance Review 27, 262-281.

Sinn, H.-W. (1997), The Selection Principle and Market Failure in Systems Competition, Journal of Public Ec onomics 66, 247-274.

Sinn, H.-W. (2003), The New Systems Competition, Oxford, Blackwell.

Solano, P.L. (1983), Institutional Explenations of Public Expenditures Among High Income Democracies, Public Finance/Finances Publiques 38, 440-458.

Sørensen, P.B. (2002), International Tax Coordination: Regionalism versus Globalism, CESifo Working Paper No. 483, May 2001, forthcoming in: Journal of Public Economics.

Stauffer, T.P. (2001), Instrumente des Haushaltsausgleichs: Ökonomische Analyse und rechtliche Umsetzung, Ph.D.-Thesis, University of St. Gallen.

Stein, E. (1999), Fiscal Decentralization and Government Size in Latin America, Journal of Applied Economics 2, 357-391.

Stutzer, A. and B.S. Frey (2000), Stärkere Volksrechte - Zufriedenere Bürger: Eine mikroökonometrische Untersuchung für die Schweiz, Swiss Political Science Review 6, 1-30.

Trechsel, A. and U. Serdült (1999), Kaleidoskop Volksrechte: Die Institutionen der direkten Demokratie in den schweizerischen Kantonen (1970-1996). Basel, Helbing and Lichtenhahn. 
Velasco, A. (1999), A Model of Endogenous Fiscal Deficits and Delayed Fiscal Reforms, in: J.M. Poterba and J. von Hagen (eds.), Fiscal Institutions and Fiscal Performance, Chicago, Chicago University Press, 37-58.

Volkerink, B. and J. De Haan (2001), Fragmented Government Effects on Fiscal Policy: New Evidence, Public Choice 109, 221-242.

Wagner, A. (1892), Grundlegung der politischen Ökonomie, Leipzig, Winter'sche Verlagshandlung.

Wallis, J.J. and W.E. Oates (1988a), Decentralization in the Public Sector: An Empirical Study of State and Local Government, in: H.S. Rosen (ed.). Fiscal Federalism: Quantitative Studies, Chicago, Chicago University Press, 5-32.

Wallis, J.J and W.E. Oates (1988b), Does Economic Sclerosis Set in With Age? An Empirical Study of the Olson Hypothesis, Kyklos 41, 397-417.

Weingast, B.R. (1995), The Economic Role of Political Institutions: Market-Preserving Federalism and Economic Development, Journal of Law, Economics and Organisation 11, 1-31.

Weingast, B.R., K.A. Shepsle and C. Johnsen (1981), The Political Economy of Benefits and Costs: A Neocla ssical Approach to Distributive Politics, Journal of Political Economy 89, 642-664.

Wicksell, K. (1896), Finanztheoretische Untersuchungen nebst Darstellung and Kritik des Steuerwesens Schwedens, Jena, Gustav Fischer.

Wildasin, D.E. (1997), Externalities and Bailouts: Hard and Soft Budget Constraints in Intergovernmental Fiscal Relations, World Bank Policy Research Working Paper 1843.

Wilson, J.D. (1999), Theories of Tax Competition, National Tax Journal 52, 269-304.

Winer, S.L. (1983), Some Evidence on the Effect of the Separation of Spending and Taxing Decisions, Journal of Political Economy 91, 126-140.

Wrede, M. (1996), Vertical and Horizontal Tax Competition: Will Uncoordinated Leviathans End Up on the Wrong Side of the Laffer Curve?, FinanzArchiv 53, 461-479.

Wyckoff, P.G. (1991), The Elusive Flypaper Effect, Journal of Urban Economics 30, 310-328.

Zax, J.S. (1989), Is There Leviathan in Your Neighbourhood? American Economic Review 79, 560567. 
Appendix A

\begin{tabular}{|c|c|c|}
\hline \multicolumn{3}{|l|}{ Data description } \\
\hline Variable name & Description & Source \\
\hline $\begin{array}{l}\begin{array}{l}\text { Revenue } \\
\text { (structure) }\end{array} \\
\end{array}$ & Real total revenue per capita. & $\begin{array}{l}\text { Swiss Federal Finance Admini- } \\
\text { stration }\end{array}$ \\
\hline $\begin{array}{l}\text { Decentralization } \\
\text { (structure) }\end{array}$ & $\begin{array}{l}\text { Ratio between communal and commu- } \\
\text { nal plus cantonal revenue (structure) } \\
\text { per capita. }\end{array}$ & $\begin{array}{l}\text { Own calculations on the basis } \\
\text { of data from the Swiss Federal } \\
\text { Finance Administration }\end{array}$ \\
\hline Tax competition & $\begin{array}{l}\text { Weighted average of the other cantons' } \\
\text { income tax rates in the highest income } \\
\text { class of } 1 \text { million SFr taxable income; } \\
\text { Weight: Inverse of Distance. }\end{array}$ & $\begin{array}{l}\text { Own calculations on the basis } \\
\text { of data from the Swiss Federal } \\
\text { Finance Administration }\end{array}$ \\
\hline Tax exporting & Number of tourist days per canton & Swiss Federal Statistical Office \\
\hline Fragmentation & $\begin{array}{l}\text { Number of communes in a canton di- } \\
\text { vided by population. }\end{array}$ & Swiss Federal Statistical Office \\
\hline Population & Number of cantonal population & Swiss Federal Statistical Office \\
\hline Cantonal income & $\begin{array}{l}\text { Real national income per capita disag- } \\
\text { gregated to the cantons }\end{array}$ & $\begin{array}{l}\text { Swiss Federal Finance Admini- } \\
\text { stration }\end{array}$ \\
\hline Urban population & $\begin{array}{l}\text { Proportion of communes having more } \\
\text { than } 10^{\prime} 000 \text { inhabitants. }\end{array}$ & Swiss Federal Statistical Office \\
\hline Democracy & $\begin{array}{l}\text { Index designed to reflect the extent of } \\
\text { direct democratic participation possi- } \\
\text { bilities within a range between } 1 \text { (low- } \\
\text { est) and } 6 \text { (highest degree). }\end{array}$ & $\begin{array}{l}\text { Own calculations for an index } \\
\text { proposed by Stutzer and Frey } \\
\text { (2000) on the basis of data from } \\
\text { Trechsel and Serdült (1999). }\end{array}$ \\
\hline Grants & $\begin{array}{l}\text { Real net transfer payments from the } \\
\text { central government to the cantonal } \\
\text { governments per capita. }\end{array}$ & $\begin{array}{l}\text { Own calculations on the basis } \\
\text { of Swiss Federal Finance Ad- } \\
\text { ministration. }\end{array}$ \\
\hline Coalition & Number of parties in cabinet. & $\begin{array}{l}\text { Own calculations on the basis } \\
\text { of data from the cantonal go v- } \\
\text { ernments }\end{array}$ \\
\hline Homogeneity & $\begin{array}{l}\text { Ratio between the real personal income } \\
\text { of the median taxpayer compared to the } \\
\text { average taxpayer }\end{array}$ & $\begin{array}{l}\text { Own calculations on the basis } \\
\text { of the Swiss Federal Tax Ad- } \\
\text { ministration }\end{array}$ \\
\hline German language & $\begin{array}{l}\text { Dummy = } 1 \text { for German speaking can- } \\
\text { tons }\end{array}$ & Own calculations \\
\hline Unemployment & $\begin{array}{l}\text { Share of unemployment on cantonal } \\
\text { population }\end{array}$ & $\begin{array}{l}\text { Own calculations on the basis } \\
\text { of Swiss Federal Statistical Of- } \\
\text { fice }\end{array}$ \\
\hline Budget rules & $\begin{array}{l}\text { Dummy }=1 \text { for cantons having a } \\
\text { budget rule for a given year }\end{array}$ & $\begin{array}{l}\text { Own calculations on the basis } \\
\text { of Stauffer (2001) }\end{array}$ \\
\hline
\end{tabular}




\section{CESifo Working Paper Series}

(for full list see www.cesifo.de)

1023 Patrick Karl O'Brien, The Governance of Globalization: The Political Economy of Anglo-American Hegemony, 1793-2003, September 2003

1024 Antonio Ciccone and Giovanni Peri, Skills' Substitutability and Technological Progress: U.S. States 1950-1990, September 2003

1025 Bjørn Sandvik, Optimal Taxation and Normalisations, September 2003

1026 Massimo Bordignon and Gilberto Turati, Bailing Out Expectations and Health Expenditure in Italy, September 2003

1027 José A. Herce, Namkee Ahn, Ricard Génova, and Joaquín Pereira, Bio-Demographic and Health Aspects of Ageing in the EU, September 2003

1028 John Komlos and Marieluise Baur, From the Tallest to (One of) the Fattest: The Enigmatic Fate of the American Population in the $20^{\text {th }}$ Century, September 2003

1029 Stefan Napel and Mika Widgrén, Bargaining and Distribution of Power in the EU's Conciliation Committee, September 2003

1030 Kai Li and Dale J. Poirier, Relationship Between Maternal Behavior During Pregnancy, Birth Outcome, and Early Childhood Development: An Exploratory Study, September 2003

1031 Ivar Ekeland, James J. Heckman, and Lars Nesheim, Identifcation and Estimation of Hedonic Models, September 2003

1032 Kjetil Bjorvatn and Alexander W. Cappelen, Decentralization and the Fate of Minorities, September 2003

1033 Lars-Erik Borge and Jørn Rattsø, The Relationships Between Costs and User Charges: The Case of a Norwegian Utility Service, September 2003

1034 Maureen Were and Nancy N. Nafula, An Assessment of the Impact of HIV/AIDS on Economic Growth: The Case of Kenya, September 2003

1035 A. Lans Bovenberg, Tax Policy and Labor Market Performance, September 2003

1036 Peter Birch Sørensen, Neutral Taxation of Shareholder Income: A Norwegian Tax Reform Proposal, September 2003

1037 Roberta Dessi and Sheilagh Ogilvie, Social Capital and Collusion: The Case of Merchant Guilds, September 2003 
1038 Alessandra Casarico and Carlo Devillanova, Capital-skill Complementarity and the Redistributive Effects of Social Security Reform, September 2003

1039 Assaf Razin and Efraim Sadka, Privatizing Social Security Under Balanced-Budget Constraints: A Political-Economy Approach, September 2003

1040 Michele Moretto, Paolo M. Panteghini, and Carlo Scarpa, Investment Size and Firm's Value under Profit Sharing Regulation, September 2003

1041 A. Lans Bovenberg and Peter Birch Sørensen, Improving the Equity-Efficiency Tradeoff: Mandatory Savings Accounts for Social Insurance, September 2003

1042 Bas van Aarle, Harry Garretsen, and Florence Huart, Transatlantic Monetary and Fiscal Policy Interaction, September 2003

1043 Jerome L. Stein, Stochastic Optimal Control Modeling of Debt Crises, September 2003

1044 Thomas Stratmann, Tainted Money? Contribution Limits and the Effectiveness of Campaign Spending, September 2003

1045 Marianna Grimaldi and Paul De Grauwe, Bubbling and Crashing Exchange Rates, September 2003

1046 Assar Lindbeck and Dennis J. Snower, The Firm as a Pool of Factor Complementarities, September 2003

1047 Volker Grossmann, Firm Size and Diversification: Asymmetric Multiproduct Firms under Cournot Competition, September 2003

1048 Dan Anderberg, Insiders, Outsiders, and the Underground Economy, October 2003

1049 Jose Apesteguia, Steffen Huck and Jörg Oechssler, Imitation - Theory and Experimental Evidence, October 2003

1050 G. Abío, G. Mahieu and C. Patxot, On the Optimality of PAYG Pension Systems in an Endogenous Fertility Setting, October 2003

1051 Carlos Fonseca Marinheiro, Output Smoothing in EMU and OECD: Can We Forego Government Contribution? A Risk Sharing Approach, October 2003

1052 Olivier Bargain and Nicolas Moreau, Is the Collective Model of Labor Supply Useful for Tax Policy Analysis? A Simulation Exercise, October 2003

1053 Michael Artis, Is there a European Business Cycle?, October 2003

1054 Martin R. West and Ludger Wößmann, Which School Systems Sort Weaker Students into Smaller Classes? International Evidence, October 2003

1055 Annette Alstadsaeter, Income Tax, Consumption Value of Education, and the Choice of Educational Type, October 2003 
1056 Ansgar Belke and Ralph Setzer, Exchange Rate Volatility and Employment Growth: Empirical Evidence from the CEE Economies, October 2003

1057 Carsten Hefeker, Structural Reforms and the Enlargement of Monetary Union, October 2003

1058 Henning Bohn and Charles Stuart, Voting and Nonlinear Taxes in a Stylized Representative Democracy, October 2003

1059 Philippe Choné, David le Blanc and Isabelle Robert-Bobée, Female Labor Supply and Child Care in France, October 2003

1060 V. Anton Muscatelli, Patrizio Tirelli and Carmine Trecroci, Fiscal and Monetary Policy Interactions: Empirical Evidence and Optimal Policy Using a Structural New Keynesian Model, October 2003

1061 Helmuth Cremer and Pierre Pestieau, Wealth Transfer Taxation: A Survey, October 2003

1062 Henning Bohn, Will Social Security and Medicare Remain Viable as the U.S. Population is Aging? An Update, October 2003

1063 James M. Malcomson, Health Service Gatekeepers, October 2003

1064 Jakob von Weizsäcker, The Hayek Pension: An efficient minimum pension to complement the welfare state, October 2003

1065 Joerg Baten, Creating Firms for a New Century: Determinants of Firm Creation around 1900 , October 2003

1066 Christian Keuschnigg, Public Policy and Venture Capital Backed Innovation, October 2003

1067 Thomas von Ungern-Sternberg, State Intervention on the Market for Natural Damage Insurance in Europe, October 2003

1068 Mark V. Pauly, Time, Risk, Precommitment, and Adverse Selection in Competitive Insurance Markets, October 2003

1069 Wolfgang Ochel, Decentralising Wage Bargaining in Germany - A Way to Increase Employment?, November 2003

1070 Jay Pil Choi, Patent Pools and Cross-Licensing in the Shadow of Patent Litigation, November 2003

1071 Martin Peitz and Patrick Waelbroeck, Piracy of Digital Products: A Critical Review of the Economics Literature, November 2003

1072 George Economides, Jim Malley, Apostolis Philippopoulos, and Ulrich Woitek, Electoral Uncertainty, Fiscal Policies \& Growth: Theory and Evidence from Germany, the UK and the US, November 2003 
1073 Robert S. Chirinko and Julie Ann Elston, Finance, Control, and Profitability: The Influence of German Banks, November 2003

1074 Wolfgang Eggert and Martin Kolmar, The Taxation of Financial Capital under Asymmetric Information and the Tax-Competition Paradox, November 2003

1075 Amihai Glazer, Vesa Kanniainen, and Panu Poutvaara, Income Taxes, Property Values, and Migration, November 2003

1076 Jonas Agell, Why are Small Firms Different? Managers’ Views, November 2003

1077 Rafael Lalive, Social Interactions in Unemployment, November 2003

1078 Jean Pisani-Ferry, The Surprising French Employment Performance: What Lessons?, November 2003

1079 Josef Falkinger, Attention, Economies, November 2003

1080 Andreas Haufler and Michael Pflüger, Market Structure and the Taxation of International Trade, November 2003

1081 Jonas Agell and Helge Bennmarker, Endogenous Wage Rigidity, November 2003

1082 Fwu-Ranq Chang, On the Elasticities of Harvesting Rules, November 2003

1083 Lars P. Feld and Gebhard Kirchgässner, The Role of Direct Democracy in the European Union, November 2003

1084 Helge Berger, Jakob de Haan and Robert Inklaar, Restructuring the ECB, November 2003

1085 Lorenzo Forni and Raffaela Giordano, Employment in the Public Sector, November 2003

1086 Ann-Sofie Kolm and Birthe Larsen, Wages, Unemployment, and the Underground Economy, November 2003

1087 Lars P. Feld, Gebhard Kirchgässner, and Christoph A. Schaltegger, Decentralized Taxation and the Size of Government: Evidence from Swiss State and Local Governments, November 2003 